\title{
The effect of selenium source on the oxidative status and performance of broilers reared at standard and high ambient temperatures
}

\section{by Woods, S.L., Rose, S.P., Whiting, I.M., Yovchev, D.G., Ionescu C., Blanchard, A., Pirgozliev, V. \\ Copyright, publisher and additional information: .This is the authors' accepted manuscript. The published version is available via Taylor \& Francis.}

Please refer to any applicable terms of use of the publisher University 


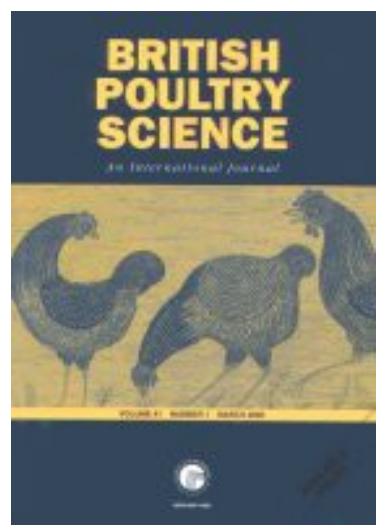

\section{The effect of selenium source on the oxidative status and performance of broilers reared at standard and high ambient temperatures}

\begin{tabular}{|r|l|}
\hline Journal: & British Poultry Science \\
\hline Manuscript ID & CBPS-2020-237.R2 \\
\hline Manuscript Type: & Original Manuscript \\
\hline Author: & 21-Jul-2020 \\
\hline Complete List of Authors: & $\begin{array}{l}\text { Woods, Sarah; Harper Adams University, National Institute of Poultry } \\
\text { Husbandry } \\
\text { Rose, Stephen; Harper Adams University College, National Institute of } \\
\text { Poultry Husbandry } \\
\text { Whiting, Izzy; 1, National Institute of Poultry Husbandry } \\
\text { Yovchev, David; Trakia University Stara Zagora, Faculty of Veterinary } \\
\text { Medicine } \\
\text { Ionescu, Catherine; Pancosma } \\
\text { Blanchard, Alexandra; Pancosma } \\
\text { Pirgozliev, Vasil; Harper Adams University, National Institute of Poultry } \\
\text { Husbandry }\end{array}$ \\
\hline Keywords: & \begin{tabular}{l} 
rearing temperature, selenium, antioxidant, FCR, unsaturated fat \\
\hline
\end{tabular} \\
\hline
\end{tabular}

\section{SCHOLARONE \\ Manuscripts}



1 The effect of selenium source on the oxidative status and performance of broilers 2 reared at standard and high ambient temperatures

3 S. L. WOODS ${ }^{1}$, S. P. ROSE 1 , I. M. WHITING ${ }^{1}$, D. G. YOVCHEV ${ }^{2}$, C. IONESCU ${ }^{3}$, A. $4 \quad$ BLANCHARD $^{3}$ AND V. PIRGOZLIEV ${ }^{1}$

${ }^{1}$ National lnstitute of Poultry Husbandry, Harper Adams University, TF10 8NB, UK

${ }^{2}$ Faculty of Veterinary Medicine, Trakia University, 6000 Stara Zagora, Bulgaria

$8 \quad{ }^{3}$ Pancosma, 1180 Rolle, Switzerland

Corresponding author: Dr V. Pirgozliev

Email: vpirgozliev@,harper-adams.ac.uk retention (NR).

2. The experiment started at $14 \mathrm{~d}$ of age, when 240 birds were randomly allocated to 48 pens (12 pens in four rooms). Treatments included a control diet 1 (SFC; $209.4 \mathrm{~g} / \mathrm{kg} \mathrm{CP}$ and 12.98 ME with no added Se containing unsaturated fat as rapeseed oil); diet 4 (USFSe) was the

29 latter control plus $12.605 \mathrm{mg} / \mathrm{kg}$ Se additive. Two rooms were kept at a standard temperature of $20^{\circ} \mathrm{C}(\mathrm{ST})$ and two rooms were kept at high temperature of $35^{\circ} \mathrm{C}(\mathrm{HT})$. 
31 3. A temperature $x$ Se interaction existed for GSH-Px in birds reared at $\mathrm{ST}(\mathrm{P}<0.05)$, these

32 birds had the highest levels of Se in liver tissue $(\mathrm{P}<0.001)$. A fat $\mathrm{x}$ Se interaction was evident

33 for breast tissue with highest levels in USFSe $(\mathrm{P}<0.05)$. Adding Se improved jejunal

34 villus morphometry in the USF fed birds.

35 4. Birds reared at ST had higher FI and WG than those reared at $\mathrm{HT}(\mathrm{P}<0.001)$, and had

36 lower FCR than those reared at HT $(\mathrm{P}<0.05)$. AMEn $(\mathrm{MJ} / \mathrm{kg} \mathrm{DM})$ and FR were higher in

37 birds fed USF diets, and lowest in birds fed $\mathrm{SF}(\mathrm{P}<0.50$ and $\mathrm{P}<0.001$ respectively). NR was

38 highest in birds raised at $\mathrm{ST}(\mathrm{P}<0.50)$.

39 5. Broiler growth performance was reduced by HT. Oxidative status and Se in liver tissue 40 was improved by adding Se in both diets.

41

Key words: Rearing temperature, selenium, antioxidant, FCR, unsaturated fat

\section{INTRODUCTION}

Birds are particularly susceptible to the negative effects of heat stress because they have no

46 sweat glands, a rapid metabolism and high body temperature (Brush, 1965). Broilers high

47 feed intake and fast growth rate make them particularly prone to the negative effects ofheat

48 stress (Syafwan et al., 2011). In commercial broiler production, heat stress is one of the most

49 challenging environmental conditions and has been shown to reduce overall growth

50 performances, meat quality (Imik et al., 2012) and welfare (Lara and Rostagno, 2013). Birds

51 reared at higher temperatures have been found to have reduced antibody production, which

52 reduces immunity (Mashaly et al., 2004) and induces oxidative stress (Altan et al., 2003;

53 Lin et al., 2006). When the ambient temperature exceeds the birds' thermo-neutral zone,

54 they can experience oxidative stress, which has been reported when the temperature exceeds

$55 \quad 32^{\circ} \mathrm{C}$ (Daghir, 2008). 
56 Broiler immunity is improved by the addition of dietary antioxidants to their diets, in

57 particular selenium (Se; Surai, 2006). When supplemented in poultry diets, this important antioxidant has been reported to increase birds' immunity when they experience heat stress (Niu et al., 2009; Liao et al., 2012). Supplemental Se improves oxidative status and immune

60 function, mainly by its incorporation and synthesis into Se-containing enzymes, for example,

61 glutathione peroxidase (GSH-Px; Rotruck et al., 1973). GSH-Px is important in the cellular

62 activation, proliferation and differentiation in innate and adaptive immune responses, and is 63 an important, commonly used biomarker to determine Se status (Surai et al., 2018a, b). In addition to higher ambient temperatures, fats have been reported to influence oxidative status (Slim et al., 1996). Although fats are important and are added to broiler diets to increase feed conversion and productivity (NRC, 1994), previous authors have reported that unsaturated

67 fatty acids increase free radical production and the animal's susceptibility to develop oxidative stress, compared to saturated fats (Slim et al., 1996; Lemieux et al., 2011). Leeson et al. (2008) reported that hens had higher GSH-Px when fed diets containing rancid canola oil, compared to those fed diets containing fresh oil.

To date, a comparison of broiler oxidative status and performance using a Se proteinate

72 source (with or without unsaturated and saturated fats) fed to broilers when they are raised

73 at different temperatures has not been studied. Therefore, the main objectives of this study

74 were to compare broiler oxidative status and performance when the birds were fed diets,

75 with or without Se proteinate, as well as saturated and unsaturated fat, when raised at two

76 different constant temperatures of $20^{\circ} \mathrm{C}$ and $35^{\circ} \mathrm{C}$.

\section{$77 \quad$ Materials and methods}

\section{Experimental diets}

79 All experimental diets were formulated to meet or exceed breeder's recommendations

80 (Aviagen Limited, Edinburgh, UK) and fed as mash (Table 1). The same starter diet was fed 
81 to all birds from one-day-old to $13 \mathrm{~d}$ age. From 14 to $35 \mathrm{~d}$ of age, the birds were fed one of

82 four experimental diets as follows; a control diet (diet $1 \mathrm{SFC}$ ) containing $635.5 \mathrm{~g} / \mathrm{kg}$ wheat, and $280 \mathrm{~g} / \mathrm{kg}$ soybean meal, as main ingredients, formulated to be adequate in crudeprotein (CP $209.4 \mathrm{~g} / \mathrm{kg}$ ) and energy (ME $12.98 \mathrm{MJ} / \mathrm{kg}$ ) and $50 \mathrm{~g} / \mathrm{kg}$ of saturated fat (Megalac ${ }^{\circledR}$, Volac $\mathrm{mg} / \mathrm{kg}$ Se proteinate (B-TRAXIM ${ }^{\circledR}$ Se, Pancosma, 1180 Rolle, Switzerland). B-TRAXIM ${ }^{\circledR}$

87 Se is an organic compound formed by a process which incorporates an inorganic Se toform contained $625.5 \mathrm{~g} / \mathrm{kg}$ wheat, $280 \mathrm{~g} / \mathrm{kg}$ soybean meal and $50 \mathrm{~g} / \mathrm{kg}$ of unsaturated fat (rapeseed oil) as main ingredients, and no added Se in premix, was formulated to contain $208.2 \mathrm{~g} / \mathrm{kg}$ $\mathrm{CP}$ and $13.10 \mathrm{MJ} / \mathrm{kg} \mathrm{ME}$, and diet 4 (USFSe) was the USFC plus $12.605 \mathrm{mg} / \mathrm{kg} \mathrm{Se}$ proteinate. Diets were mixed by Target Feeds Ltd., Whitchurch, Shropshire, UK. Oxidative status was determined by measuring GSH-Px activity in blood and total antioxidant status (TAS) in plasma. Other measurements included bird feed intake (FI); weight gain (WG) and feed conversion ratio (FCR); Se content in breast and liver tissues, percentage (\%) weight of

\section{Animal husbandry} organs in relation to body weight (BW); apparent metabolisable energy adjusted for nitrogen (AMEn); dry matter retention (DMR); fat retention (FR) and nitrogen retention (NR).

The study was approved by Harper Adams University Research Ethics Committee. Two 100 hundred and seventy, male Ross 308 broiler chicks were obtained from a commercial hatchery (Cyril Bason Ltd., Craven Arms, UK). On arrival, all the chicks were placed in a communal pen with a concrete floor covered with wood shavings for bedding in a controlled environmental room. The temperature was kept at $32^{\circ} \mathrm{C}$ for the first day and gradually reduced in accordance with breeder's recommendations over time (Aviagen Ltd., UK). At

105 the start of the experiment (14 d age), 240 birds were weighed and randomly allocated to 48 raised floor pens $\left(0.36 \mathrm{~m}^{2}\right.$ floor area; five birds per pen). The birds were separated intofour 
107

108

rooms. In two of the rooms, the temperature was reduced in accordance with the breeders' specifications and then maintained at $20^{\circ} \mathrm{C}$ (Aviagen Ltd., UK) after $20 \mathrm{~d}$ of age, and in the other two rooms, a constant temperature of $35^{\circ} \mathrm{C}$ was maintained from $14 \mathrm{~d}$ of age for the entire study period. Each pen was equipped with a separate feeder tray in front and two nipple drinkers inside the pen and absorptive material was used for bedding. Each of the four experimental diets were fed in the 12 pens following randomisation. Lighting was provided to meet the breeders' recommendations (Aviagen Ltd., UK). In the rooms that were kept at $35^{\circ} \mathrm{C}$, the relative humidity was maintained at $50 \%(+/-10 \%)$ and in the rooms that were maintained at $20^{\circ} \mathrm{C}$, the humidity was kept at $40 \%(+/-10 \%)$. Food and water were fed $a d$ libitum for the duration of the experiment. Birds were checked twice daily for overall health, food and water supply, temperature, ventilation and any unexpected events.

\section{Sample collection}

During the last three days of the experiment, between 33 and $35 \mathrm{~d}$ of age, the floor of each pen was replaced with a wire mesh and plastic trays were placed underneath to collect excreta. Samples were collected (after removing any loose feathers and feed residuals), dried at $60^{\circ} \mathrm{C}$ in a forced draft oven for two days, then reweighed and milled through a $0.75 \mathrm{~mm}$ screen (Retsch ZM 200, Retsch GmBH, Germany). Birds and feed were weighed at 14 and $35 \mathrm{~d}$ of age, and performance variables such as WG, FI and FCR were determined. At the end of the study at $35 \mathrm{~d}$ of age, one bird per pen was selected at random, electrically stunned and blood was removed in $6 \mathrm{ml}$ heparin coated tubes (Midmeds Limited, Hertford, UK) from the jugular vein. The organs from the gastrointestinal tract (GIT), including the proventriculus and gizzard (PG), duodenum, pancreas, jejunum, ileum, caeca, liver, spleen and the heart were immediately collected and weighed. Approximately $50 \mathrm{~g}$ from the left breast from each euthanised bird was collected. Breast and liver samples were stored at $80^{\circ} \mathrm{C}$ before being analysed for Se content. Approximately $5 \mathrm{~cm}$ of the middle part of the 
132 jejunum, between the point of bile duct entry and Meckel's diverticulum, from one of the birds was sampled and stored in 10\% formalin-buffered saline before further processing.

$134 \quad$ Laboratory analysis

135 Dry matter (DM) in feed and excreta samples were determined by drying samples in a forced 136 draft oven at $105^{\circ} \mathrm{C}$ to a constant weight (AOAC 2012; method 934.01). The gross energy 137 (GE) values of feed and excreta samples were determined in a bomb calorimeter (model 6200; Parr Instrument Co., Moline, IL, USA). Se in feed, liver and breast samples were determined by inductively coupled plasma emission spectrometry (Optima 4300 DV Dual View ICP-OE spectrometer, Perkin-Elmer, Beaconsfield, UK), as described by Tanner et al.

141 (2002). The GSH-Px and TAS were determined in a Cobas Mira auto-analyser (ABX 142 Diagnostics, Bedfordshire, UK). The GSH-Px assay was determined in blood using a Ransel 143 GSH-Px kit (Randox Laboratories Ltd., Crumlin, UK), as described by Paglia and Valentine 144 (1967), and the TAS in plasma was determined using a Ransel TAS kit (Randox Ltd.) 145 following manufacturer's recommendations.

146 The relative empty weights of the GIT segments, including spleen and heart, from each bird, 147 were determined as previously described (Abdulla et al., 2017; Pirgozliev et al., 2019). The 148 collected jejunal samples were stored for two weeks in $10 \%$ formalin buffered saline, then 149 embedded in paraffin wax, sectioned at approximately $5 \mu \mathrm{m}$ and the four gut segments were 150 fixed in each slide, as previously described by Yovchev et al. (2019). Villus height (VH) was 151 measured from the tip of the villus to the villus-crypt junction; villus width (VW) was taken 152 at the midline of the villus; crypt depth (CD), measured from the crypt mouth to the base. All measurements were determined on 20 intact well-oriented villus-crypt units for each bird.

\section{Calculations}

155 Dietary AMEn was determined, as described by Hill and Anderson (1958)

$$
A M E n=\frac{(F I x G E \text { diet })-(\text { Excreta output } x \text { GE excreta })-(N \text { retained } x 34.39)}{F I(\mathrm{~kg})}
$$


157

158

159

160

161

162

163

164

165

166

167

168

169

170

171

172

173

174

175

176

177

178

179

180

The coefficient of nitrogen retention (NR), fat retention (FR) and dry matter retention (DMR)

were determined as the difference between nutrient intake and excretion of each nutrient, divided by the nutrient intake.

\section{Nutrient retention coefficient}

$$
=\frac{(\text { FI x nutrient diet })-(\text { Excreta output } x \text { nutrient excreta })}{\text { FI } x \text { nutrient diet }}
$$

The relative development of organs was determined as follows:

$$
\% \text { Organ weight }=\frac{\text { Organ weight }}{\text { Bodyweight }} \times 100 \%
$$

where organ and body weight were from each bird, respectively.

\section{Statistical analysis}

Data were statistically analysed using the ANOVA split plot design, with a 2 × 2 × 2 factorial arrangement of treatments. The treatments factors were temperature $\left(20^{\circ} \mathrm{C}\right.$ and $\left.35^{\circ} \mathrm{C}\right), \mathrm{Se}$ proteinate (with and without) and fat source (unsaturated and saturated fat). Statistical analyses were performed using GenStat (GenStat, $18^{\text {th }}$ edition; Lawes Agricultural Trust, VSN International Ltd., Oxford, UK). For interactions, Tukey's range test was used to separate differences in the means.

\section{Results}

Dietary chemical composition is presented in Table 1 . The determined CP content in all diets were relatively close to the calculated one. The control diet based on SF had slightly lower fat content. The Se level in the starter diet was $0.217 \mathrm{mg} / \mathrm{kg}$. In the experimental diets, the Se level was $0.187,0.247,0.193$ and 0.251 , for diets $1,2,3$ and 4 , respectively. 
Table 1 here

Mortality was low (2.5\%) and not related to treatment. Temperature influenced FI and WG, and birds reared at high ambient temperatures consumed less feed and gained less weight than those reared at standard temperature $(\mathrm{P}<0.001$; Table 2). Similarly, birds reared at high temperature had higher FCR, i.e. lower feed efficiency, than those reared at standard temperature ( $\mathrm{P}<0.05$; Table 2). A tendency was found for Se to influence FCR, as birds fed the control diet had a tendency for lower FCR than those given supplemental Se proteinate $(\mathrm{P}=081 ;$ Table 2).

Table 2 here

The highest GSH-Px was found in tissues from birds fed Se proteinate supplemented diets compared with those fed the control $\operatorname{diet}(\mathrm{P}<0.001$; Table 3$)$. There was a temperature $\mathrm{x}$ Se proteinate interaction, as the highest GSH-Px was seen in birds fed Se proteinate andreared at $20^{\circ} \mathrm{C}$, but there was no response at the high ambient temperature $(\mathrm{P}<0.05$; Table 3$)$. Total antioxidant status did not elicit any significant differences in results $(\mathrm{P}>0.50$; Table 3$)$.

Table 3 here

There was a fat source $\mathrm{x}$ Se proteinate interaction, as birds fed USFSe had higher Se content 202 in their breast muscle $(\mathrm{P}<0.05)$, although there was no response in the saturated fat diets 203 (Table 3). The Se proteinate fed birds reared at $20^{\circ} \mathrm{C}$ had the highest concentration of hepatic 204 Se $(\mathrm{P}<0.05)$, but, at higher ambient temperature, there was no difference in Se concentration 205 in the liver (Table 3). 
206 Percentage weight of organs in relation to BW was influenced by temperature for some

207 208 209

210 211

212 The results for dietary available energy and nutrient retention coefficients are presented in 213 Table 5. Dietary AMEn and FR were higher in birds fed USF diets compared to SF fed birds 214 215 216 217 218

219

220

organs. Birds raised at $35^{\circ} \mathrm{C}$ had reduced percentage weight $(\mathrm{P}<0.05)$ of small intestine, spleen, liver and heart compared with those raised at $20^{\circ} \mathrm{C}$ (Table 4).

Table 4 here

$(\mathrm{P}<0.05$ and $\mathrm{P}<0.001$, respectively). Nitrogen retention was highest in those birds raised at $20^{\circ} \mathrm{C}$ compared with those raised at $35^{\circ} \mathrm{C}(\mathrm{P}<0.50$; Table 5).

Table 5 here

There was fat source $x$ Se proteinate interaction for $\mathrm{VH}(\mathrm{P}<0.05)$, VW $(\mathrm{P}<0.001)$, CD $(\mathrm{P}<0.001)$ and $\mathrm{VH}: \mathrm{CD}$ ratio $(\mathrm{P}<0.001$; Table 6). Birds fed USF with added Se had higher VH, VW, CD and VH: CD, although feeding USF alone produced higher VH and CD compared to birds fed SF and Se. Birds fed USF plus Se had higher VH:CD compared to the other groups.

Table 6 here

\section{Discussion}

This study evaluated the effect of supplementing diets with Se proteinate on tissue Se retention and oxidative status of broiler chickens reared at standard and high ambient temperatures. Studying the interaction between dietary antioxidants and temperatures is 
231 commercially important, because of the large variation in the ambient temperature in poultry

232

233

235

\section{Effects of selenium proteinate}

Glutathione peroxidase is a well reported Se-containing enzyme associated with important free radical scavenging ability via oxidative and reductive pathways (Kosower and Kosower, 1978; Kidd, 1997; Surai, 2002). Higher oxidative status is be expected in animals fed more antioxidants (Woods et al., 2020a, b) which was confirmed in the current study whereby birds fed Se proteinate had higher levels of GSH-Px compared with those fed control diets at both temperatures. The observed levels were in accordance with other studies (Leeson et al., 2008; Saadat-Shad et al., 2016). In the present study, birds fed Se proteinate at $20^{\circ} \mathrm{C}$ had higher oxidative status (GSH-Px), compared with those fed the control diets at $35^{\circ} \mathrm{C}$, and numerical differences were seen at higher temperatures, but were not significant. It may be that increasing product levels of Se proteinate in feed could elicit higher levels of GSH-Px when the birds are raised at higher temperatures, but different levels of Se proteinate were not tested in the current study.

Dietary fats are oxidised at different rates, depending on their chemical structure, with unsaturated fats (containing at least one double carbon bond) reported as having higher susceptibility to free radical damage compared with those fed saturated fat diets (Leyton et Accepted for publication 4 August 2020 
al., 1987). Indeed, reports by Sanz et al. (2000) and Ghazalah et al. (2008) showed an increase in tissue lipid peroxidation and reduced antioxidative status in broiler fed USF (sunflower oil, fish oils) compared to broilers fed SF (beef tallow or lard). Thus, it was expected in the current study that animals fed diets containing USF would have reduced oxidative status compared with those fed SF, i.e. lower TAS and GSH-Px. However, this was not found to be the case. In support, recent research (Febel et al., 2008; Upton et al., 2009; Khajali and Fahimi, 2010) did not find an effect on oxidative status in broilers fed different fat sources (beef tallow, soy oil, mixture of fats).

Usually, birds fed Se supplemented diets have higher hepatic Se levels and better oxidative status compared with birds fed non supplemented diets (Wang and Xu, 2008; Celi et al., 2014; Chadio et al., 2015; Woods et al., 2020a). However, in the current study, high GSHPx in broilers fed selenium proteinate and reared at $20^{\circ} \mathrm{C}$ was also seen with Se concentration in the liver of the same birds. Thus, increased hepatic Se concentration suggested an improved antioxidant status that may help birds sustain performance when exposed to stressful commercial conditions. In agreement, Leeson et al. (2008) reported improved antioxidant status, as reduced malonaldehyde, in breast tissue in hens fed the same source of Se proteinate, and Nyguist et al. (2013) showed that Se concentration in liver tissue was not affected by the source of fat. The fact that birds fed USFC had low Se in breast tissue supported the view that supplementation may indeed offer some protection in those tissues experiencing higher states of oxidative stress.In contrast with previous studies by Sevcikova et al. (2006), who reported improved WG and FCR in broilers fed Se enriched diets, the current study found no difference in WG between birds fed the un-supplemented control and Se proteinate diets. Although no Sewas added to control diets in the current study, it seems that the dietary ingredients contained enough background Se to meet the requirements of the birds. The levels of Se in the control diets

(diet $1: \mathrm{SFC}=0.187 \mathrm{mg} / \mathrm{kg} \mathrm{Se}$; diet $3: \mathrm{USFC}=0.193 \mathrm{mg} / \mathrm{kg} \mathrm{Se})$ were in accordance 
283 with minimum NRC recommended guidelines $(0.150 \mathrm{mg} / \mathrm{kg})$ which explains the reported

284 lack of influence of birds fed Se proteinate diets on growth performances and organ development, because they had above the minimum recommended allowance.

285

286

287

288

289

290

291

292

293

294

295

In the current study, villus morphometry was improved by Se proteinate when added to diet based on USF compared to SF. In agreement, research by Safdari-Rostamabad et al. (2017) and Pirgozliev et al. (2020) found an increase in VH for chickens fed more antioxidants.

Similar to the current research, Józefiak et al. (2016) found an increase in small intestinal VH in birds fed palm kernel distillers fatty acids (USF) compared to those fed beef tallow (SF). Longer villi are associated with better feed utilisation and performance of poultry (Józefiak et al., 2016; Safdari-Rostamabad et al., 2017). Although not supported by performance and energy metabolism data for the Se proteinate diet groups in the current study, this could be true for the fat sources, where longest villi were observed in birds fed on diets with inclusion of USF, which was correlated with improved AMEn and FR.

An increase in hepatic antioxidant status is reflected with improved dietary available energy (Pirgozliev et al., 2015), although studies reporting comparisons for AME in Se supplemented diets are limited. No differences in dietary AME were found in the current study, which agreed with previous reports (Choct et al., 2004; Woods et al., 2020a). As AME is a measurement of the available energy in carbohydrates, fats and proteins, it was expected that different sources of Se would not greatly impact AME.

The birds fed USF had higher AMEn and higher FR compared to those fed SF. This agreed with Mateos and Sell (1980) and was expected, because unsaturated fats contain higher levels of fatty acids which are more easily digested and metabolised.

In agreement with many published papers (Sanz., 1999; Pietras et al., 2000; Celebi and Utlu, 2004; Jimenez-Moreno et al., 2009), fat source had no effect on broiler growth performance and organ developments in the current study. Although there have been some reports that contradicted these findings (Peebles et al., 1999; Poorghasemi et al., 2013) comparisons 


\section{Effects of ambient temperature}

310 Although it is often claimed that high rearing temperatures leads to higher mortality, there

311 were no mortalities in the current study due to high ambient temperature. The antioxidant 312 status in birds was determined by measuring TAS and GSH-Px activity. These systems 313 utilise all free radical (ROS) scavengers to protect cells from oxidative damage (Jacob, 314 1995). However, exposure to high temperatures, i.e. heat stress, may disturb the balance between the production of free radicals and the antioxidant system in chickens (Lin et al., 2006). As temperature increases, oxidative stress is expected to increase and the animal's overall GSH-Px and TAS levels would concurrently decrease (Ma et al., 2014; Huang et al., 2015; Sarica et al., 2017; Mazur-Kuśnirek et al., 2019). Feeding Se proteinate to birds reared at $20^{\circ} \mathrm{C}$ in this study led to higher GSH-Px, thus providing potential protection against ROS. However, in disagreement with previous reports, GSH-Px and TAS in birds were unaffected by the high rearing temperature. A potential reason for this discrepancy may have been the use of birds from different strains, age, prolonged exposure to high temperature and dietary

323 formulation. Indeed, the levels of Se in the control diets were in accordance with minimum $324 \mathrm{NRC}$ recommended guidelines $(0.15 \mathrm{mg} / \mathrm{kg})$, thus providing an explanation for the reported 325 lack of influence of Se proteinate on oxidative status. However, the interaction between Se and temperature regarding GSH-Px correlated with the relatively high hepatic Se content,

327 suggesting more resources in birds reared at ST. In addition, the use of GSH-Px as a 328 biomarker for Se based products may be more reliable than the overall TAS test.

329 In the current study, the decrease in FI, WG and increase in FCR in birds reared at HT was expected and in agreement with others (Sonaiya, 1989; Quinteiro-Filho et al., 2010).

331 Reductions of FI (45.1\%) and WG (57.6\%) in birds raised at $35^{\circ} \mathrm{C}$ were higher compared to 332 a heat trial in broilers undertaken by Sohail et al. (2012), who reported reductions of $16.4 \%$ and $32.6 \%$ for FI and WG, respectively. A possible explanation could be that the birds used 
335 acclimatisation. In addition, these authors compared probiotics and prebiotics and not dietary

Se. However, despite these disparities, there was a comparable difference in FCR in birds raised at normal and higher temperature, $25.6 \%$ in theirs and $26.6 \%$ the current study. Birds raised at higher temperatures have reduced FI due to lower metabolic heat production. Hai et al. (2000) described that this is, in part, due to the suppression of digesta being expelled from the crop or small intestine. As expected, the reduction in FI in birds reared at higher temperature in the current study had a corresponding reduction in NR, which agreed with others (Farrel and Swain, 1977; Bonnet et al., 1997 and Sonaiya, 1989).

The effect of temperature on organ weight in relation to body weight were not uniform in the current trial. As expected, the weights of most organs, including the small intestine, spleen, liver and heart, were all proportionally lighter from birds raised at $35^{\circ} \mathrm{C}$ compared to those raised at $20^{\circ} \mathrm{C}$. As broilers are bred to eat and grow rapidly, their organs should be able to maintain this efficient system when reared at normal temperatures. Other researchers (Yahav, 1999) agreed with the current findings, in that relative heart weight (in proportion to body weight) was lower in broilers reared at high temperatures. However, in the current study, the relative weights of the proventriculus and gizzard, pancreas and caeca were not significantly reduced by high temperature, compared to those raised at standard temperatures. This disagreed with findings from other researchers. For instance, Sonaiya, (1989) reported that, whilst heart weight decreased in broilers reared at higher temperatures, gizzard weight actually increased. The reported study measured both the gizzard and proventriculus, although only the gizzard was measured by Sonaiya, (1989), thus providing a potential explanation for the discrepancies in both studies.

Histomorphological and morphometric analyses of the intestines indicated that the duodenum and jejunum showed more damage than the ileum under heat stress (Santos et al., 2015). The same authors found that major alterations in the control intestines were limited to the villus tips, while heat stress led to villus denudation and crypt damage. When Accepted for publication 4 August 2020 
361 compared with morphologically normal villi, in heat stressed birds a reduction in $\mathrm{VH}$ and CD of jejunum were observed, but not in VW and VH:CD ratio (Santos et al., 2015). Ashraf et al. (2013) observed a reduction in height, width and epithelial cell area of jejunal villi in heat exposed broilers. Surprisingly there was not a reduction in VH in the current study, although the lack of response in VW and VH:CD to high temperature agreed with the findings of Santos et al. (2015).

Research on the impact of high ambient temperature on AME and nutrient availability in poultry is inconsistent. Bonnet et al. (1997) showed that rearing birds at $35^{\circ} \mathrm{C}$ reduced dietary AME and nutrient digestibility coefficients compared to rearing at $22^{\circ} \mathrm{C}$, although this was not consistent between dietary types. Recently, Pirgozliev et al. (2020) reported no changes in dietary AME and nutrient digestibility in birds reared at $21^{\circ} \mathrm{C}$ and at $35^{\circ} \mathrm{C}$. There

372 have been reports (Habashy et al., 2017; Attia et al., 2018) which claimed higher nutrient digestibility in birds reared at high ambient temperature. It is obvious that the lack of

374 response to ambient temperature of AME and nutrient availability in the current study agreed 375 with some and disagreed with other studies. A possible explanation for the disparity between 376 studies may be explained by the use of different strains of birds, ages, dietary composition and experimental conditions.

\section{Conclusions}

Selenium proteinate supplemented broiler diets improved birds' oxidative status, increased the subsequent deposition of Se in liver tissues and improved jejunal villus morphometry. High temperatures reduced broiler growth performance and nitrogen retention, but not metabolisable energy, dry matter or fat retention. The findings of this study are useful to poultry producers and nutritionists, and can help them make informed choices to maximise bird performance and oxidative status by producing diets that are nutritious and cost effective when rearing broilers in higher temperatures.

Accepted for publication 4 August 2020 



\section{Acknowledgements}

389

Special thanks to Richard James and Rosalind Crocker for their technical support.

\section{Funding}

This work was supported by Pancosma, Switzerland and Harper Adams University, UK.

\section{References}

ABDULLA, J., S.P. ROSE, A.M. MACKENZIE and V. PIRGOZLIEV. 2017. "Feeding

Value of Field Beans (Vicia faba L. var. minor) With and Without Enzyme Containing

397 Tannase, Pectinase and Xylanase Activities for Broilers." Archives of Animal Nutrition 71:

$398 \quad 150-164$. doi.org/10.1080/1745039X.2017.1283823

399

Altan, O., A. PABUCCUOGlu, A. Altan, S. KONYAlioglu and $\mathrm{H}$.

BAYRAKTAR. 2003. "Effect of Heat Stress on Oxidative Stress, Lipid Peroxidation and

401 Some Stress Parameters in Broilers." British Poultry Science 44: 545-550.

402 doi.org/10.1080/00071660310001618334.

AOAC 2012. ASSOCIATION OF OFFICIAL ANALYTICAL CHEMISTS. Official

Methods of Analysis.19th ed. Gaithersburg, USA.

ASHRAF, S., H. ZANEB, M. YOUSAF, M. S., A. IJAZ, M.U. SOHAIL, S. MUTI, M.M.

USMAN, S. IJAZ and H. REHMAN. 2013. "Effect of Dietary Supplementation of Prebiotics and Probiotics on Intestinal Microarchitecture in Broilers Reared under Cyclic Heat Stress.” Journal of Animal Physiology and Animal Nutrition 97: 68-73. doi.org/10.1111/jpn.12041. ATTIA, Y.A., M.A. Al-HARTHI and A. SH. ELNAGGAR1. 2018. "Productive,

410 Physiological and Immunological Responses of Two Broiler Strains Fed Different Dietary 411 Regimens and Exposed to Heat Stress." Italian Journal of Animal Science 17: 686-697. 
413 AVIAGEN 2018. "Ross 308 Broiler: Nutrition Specifications.” Accessed September 2019.

414 http://en.aviagen.com/assets/Tech_Center/Ross_Broiler/Ross308BroilerNutritionSpecs201

415 4-EN.p

416 BONNET, S., P.A. GERAERT, M. LESSIRE, B. CARRE and S. GUILLAUMIN. 1997.

417 "Effect of High Ambient Temperature on Feed Digestibility in Broilers." Poultry Science

418 76: 857-863. doi.org/10.1093/ps/76.6.857.

419 BRUSH, A. H. 1965. "Energetics, Temperature Regulation and Circulation in Resting,

420 Active and Defeathered California Quail, Lophortyx californicus." Comparative

421 Biochemistry and Physiology 15: 399-421. doi.org/10.1016/0010-406x(65)90141-6.

422 CELI, P., P.H. SELLE and A.J. COWIESON. 2014. "Effects of Organic Selenium

423 Supplementation on Growth Performance, Nutrient Utilisation, Oxidative Stress and

424 Selenium Tissue Concentrations in Broiler Chickens." Animal Production Science 54: 966-

425 971. doi.org/10.1071/AN13116.

426 CELEBI, S. and N. UTLU. 2004. "Laying Performance, Serum Lipoproteins, Cholesterol

427 and Triglyceride of Hens as Influenced by Dietary Fat Sources.” Journal of Applied Animal

428 Research 25: 121-124. doi.org/10.1080/09712119.2011.565219.

429 CHADIO, S.E., A.C. PAPPAS, A. PAPANASTASATOS, D. PANTELIA, A. 430 DARDAMANI, K. FEGEROS and G. ZERVAS. 2015. "Effects of High Selenium and Fat 431 Supplementation on Growth Performance and Thyroid Hormones Concentration of

432 Broilers." Journal of Trace Elements in Medicine and Biology 29: 202$433 \quad$ 207.doi.org/10.1016/j.jtemb.2014.09.010.

434 CHOCT, M., A.J. NAYLOR and N. Reinke. 2004. "Selenium Supplementation Affects 435 Broiler Growth Performance, Meat Yield and Feather Coverage.” British Poultry Science 436 45: 677-683. doi.org/10.1080/00071660400006495.

437 DAGHIR, N.J. 2008. "Broiler Feeding and Management in Hot Climates. In: DAGHIR, N.J. 438 ed." Poultry Production in Hot Climates $2^{\text {nd }}$ Ed. CABI. OXFORD, UK. Accepted for publication 4 August 2020 
439 https://s3.amazonaws.com/academia.edu.documents/46187279/poultry_production_in_hot

440

441

442

443

444

445 _climates.pdf.

FARRELL, D. J. and S. SWAIN. 1977. "Effects of Temperature Treatments on the Energy and Nitrogen Metabolism of Fed Chickens." British Poultry Science 1: 735748. doi.org/10.1080/00071667708416429.

FEBEL, H., M. MEZES, T. PALFY, A. HERMAN, J. GUNDEL, A. LUGASI, K. BALOGH, I. KOCSIS and A. BLAZOVICS. 2008. "Effect of Dietary Fatty Acid Pattern on Growth, Body Fat Composition and Antioxidant Parameters in Broilers." Journal of Animal Physiology and Animal Nutrition 92: 369-376. doi.org/10.1111/j.1439-0396.2008.00803.x. GHAZALAH, A.A., M.O. ABD-ELSAMEE and A.M. ALI. 2008. "Influence of Dietary Energy and Poultry Fat on the Response of Broiler Chicks to Heat Therm." International Journal of Poultry Science 7: 355-359. http://freejournal.umm.ac.id/files/file/Influence\%20of\%20Dietary $\% 20$ Energy $\% 20$ and $\% 20$ Poultry\%20Fat.pdf.

JÓZEFIAK, D., S. ŚWIATKIEWICZ, B. KIEROŃCZYK, M. RAWSKI, J. DLUGOSZ, R.M. ENGBERG and O. HØJBERG. 2016. "Clostridium Perfringens Challenge and Dietary Fat Type Modifies Performance, Microbiota Composition and Histomorphology of the Broiler Chicken Gastrointestinal Tract.” European Poultry Science, 80, ISSN 1612-9199. doi.org/10.1399/eps.2016XX.

HAI, L., D. RONG and Z.Y. ZHANG. 2000. "The Effect of Thermal Environment on the Digestion of Broilers." Journal of Animal Physiology and Animal Nutrition 83: 57-64. doi.org/10.1046/j.1439-0396.2000.00223.x.

HABASHY, W.S., M.C. MILFORT, K. ADOMAKO, Y.A. ATTIA, R. REKAYA and S.E. AGGREY. 2017. "Effect of Heat Stress on Amino Acid Digestibility and Transporters in Meat-Type Chickens.” Poultry Science 96: 2312-2319. doi.org/10.3382/ps/pex027. 
464 HILL, F.W. and D.L. ANDERSON. 1958. "Comparison of Metabolizable Energy and 465 Productive Energy Determinations with Growing Chicks." Journal of Nutrition 64: 587-603. 466 doi.org/10.1093/jn/65.4.561.

467 HUANG, C., H. JIAO, Z. SONG, J. ZHAO, X. WANG AND H. LIN. 2015. "Heat Stress 468 Impairs Mitochondria Functions and Induces Oxidative Injury in Broiler Chickens.” Journal 469 of Animal Science 93: 2144 - 2153. doi.org/10.2527/jas.2014-8739.

470 IMIK, H., M.A. ATASEVER, S. URCAR, H. OZLU, R. GUMUS and M. ATASEVER. 471 2012. "Meat Quality of Heat Stress Exposed Broilers and Effect of Protein and Vitamin E." 472 British Poultry Science 53: 689-698. doi.org/10.1080/00071668.2012.736609.

473 KHAJALI, F. and S. FAHIMI. 2010. "Influence of Dietary Fat Source and Supplementary $474 \alpha$-Tocopheryl Acetate on Pulmonary Hypertension and Lipid Peroxidation in 475 Broilers." Journal of Animal Physiology and Animal Nutrition 94: 767-772. 476 doi.org/10.1111/j.1439-0396.2009.00959.x.

477 KIDD, P.M. 1997. “Glutathione: Systemic Protectant against Oxidative and Free Radical 478

Damage." Alternative

Medicine Review 2: $155-176$.

479 http://jack_immunocal.tripod.com/VirtuaLib/9.pdf.

480 KOSOWER N.S. and E.M. KOSOWER. 1978. "The Glutathione Status of Cells."

481 In International Review of Cytology 54 109-160. Academic Press. USA. 482 doi.org/10.1016/S0074-7696(08)60166-7.

483 JACOB, R.A. 1995. “The Integrated Antioxidant System.” Nutrition Research 15: 755-766. 484 doi.org/10.1016/0271-5317(95)00041-g.

485 JIMENEZ-MORENO, E., J.M. GONZALEZ-ALVARADO, A. GONZALEZ-SERRANO, 486 R. LAZARO and G.G. MATEOS. 2009. "Effect of Dietary Fiber and Fat on Performance 487 and Digestive Traits of Broilers from One to Twenty-One Days of Age." 488 Poultry Science 88: 2562-2574. doi.org/10.3382/ps.2009-00179. 
489

490

491

492

493

494

495

496

497

498

499

500

501

502

503

504

505

506

507

508

509

510

511

512

513

LARA, L.J. and M.H ROSTAGNO. 2013. "Impact of Heat Stress on Poultry Production." Animals 3: 356-369. doi.org/10.3390/ani3020356.

LEESON, S., H. NAMKUNG, L. CASTON, S., DUROSOY and P. SCHLEGEL. 2008. “Comparison of Selenium Levels and Sources and Dietary Fat Quality in Diets for Broiler Breeders and Layer Hens.” Poultry Science 87: 2605-2612. doi.10.3382/ps.2008-00174.

LEYTON, J., P.J. DRURY and M.A. CRAWFORD. 1987. "Differential Oxidation of Saturated and Unsaturated Fatty Acids in Vivo in the Rat." British Journal of Nutrition 57: 383-393. doi.org/10.1079/BJN19870046.

LEMIEUX, H., A.L. BUlteAU, B. FRIGUET, J.C. TARDIF and P.U. BLIER. 2011. "Dietary Fatty Acids and Oxidative Stress in the Heart Mitochondria." Mitochondrion 11: 97-103.

doi.org/10.1016/j.mito.2010.07.014.

LIAO, X., L. LU, S. LI, S. LIU, L. ZHANG, G. WANG, A. LI and X. LUO. 2012."Effects of Selenium Source and Level on Growth Performance, Tissue Selenium Concentrations, Antioxidation, and Immune Functions of Heat-Stressed Broilers.” Biological Trace Element Research 150: 158-165. doi.org/10.1007/s12011-012-9517-3.

LIN, H., E. DECUYPERE and J. BUYSE. 2006. "Acute Heat Stress Induces Oxidative Stress in Broiler Chickens." Comparative Biochemistry and Physiology, Part A, Molecular and Integrative Physiology 144: 11-17. doi.org/10.1016/j.cbpa.2006.01.032.

MA, X., Y. LIN, H. ZHANG, W. CHEN, S. WANG, D. RUAN and Z. JIANG. Z. 2014. "Heat Stress Impairs the Nutritional Metabolism and Reduces the Productivity of EggLaying Ducks." Animal Reproduction Science 145: $182 \quad$ - 190. doi.org/10.1016/j.anireprosci.2014.01.002.

MASHALY, M.M., G.L. HENDRICKS 3rd, M.A KALAMA, A.E. GEHAD, A.O. ABBAS and P.H. PATTERSON. 2004. "Effect of Heat Stress on Production Parameters and Immune 
514

515

516

517

518

519

520

521

522

523

524

525

526

527

528

529

530

531

532

533

534

535

536

537

538

539

Responses of Commercial Laying Hens." Poultry Science 83: 889-894. doi.org/10.1093/ps/83.6.889.

MATEOS, G.G. and J.L. SELL. 1980. "Influence of Carbohydrate and Supplemental Fat

Source on the Metabolizable Energy of the Diet.” Poultry Science 59: 2129-2135.

doi.org/10.3382/ps.0592129.

MAZUR-KUŚNIREK, M., Z. ANTOSZKIEWCZ, K. LIPIŃSKI, J. KALINIEWICZ, S. KOTLARCZYK and P. ŻUKOWSKI. 2019. "The Effect of Polyphenols and Vitamin E on the Antioxidant Status and Meat Quality of Broiler Chickens Exposed to High Temperature.” Archives of Animal Nutrition 73: 111 - 126. doi.org/10.1080/1745039X.2019.1572342.

NATIONAL RESEARCH COUNCIL (NRC) 1994. Nutrient Requirements of Poultry. $9^{\text {th }}$ ed. Washington, USA. National Academy Press.

NIU, Z., F. LIU, Q. YAN and L. LI. 2009. "Effects of Different Levels of Selenium on Growth Performance and Immune-Competence of Broilers under Heat Stress. "Archives of Animal Nutrition" 63: 56-65. doi.org/10.1080/17450390802611610.

NYQUIST, N.F., R., RODBOTTEN, M., THOMASSEN and A. HAUG. 2013. “Chicken

Meat Nutritional Value When Feeding Red Palm Oil, Palm Oil or Rendered Animal Fat in Combinations with Linseed Oil, Rapeseed Oil and Two Levels of Selenium." Lipids in Health and Disease 12: 69-82. doi.org/10.1186/1476-511X-12-69.

PAGLIA, D.E. and W.N. VALENTINE. 1967. "Studies on the Quantitative and Qualitative Characterization of Erythrocyte and Glutathione Peroxidase." The Journal of Laboratory and Clinical Medicine 70: 158-169. https://www.translationalres.com/article/00222143(67)90076-5/.

PEEBles, E. D., S. M. DOYLE, T. O. M. A. S. PANSKY, P. D. GERARD, M. A. LATOUR, C. R. BOYLE and T. W. SMITH. 1999. "Effects of Breeder Age and Dietary Fat on Subsequent Broiler Performance. 1. Growth, Mortality, and Feed Conversion." Poultry Science 78: 505-511. doi.org/10.1093/ps/78.4.505. 
540 PIETRAS, M., T. BAROWICZ and R. GASIOR. 2000. "The Effect of Vegetable Fat

541 Supplements on Carcass Quality and Fatty Acid Profile of Meat in Broiler Chickens." Annals

542 of Animal Science-Roczniki Naukowe Zootechniki 27: 209-219.

543 https://www.cabdirect.org/cabdirect/abstract/20013023920.

544 PIRGOZLIEV, V., F. KARADAS, S. P. ROSE, A. FERNANDES BECCACCIA, M. W.

545 MIRZA, and A. M. AMERAH. 2015. "Dietary Xylanase Increases Hepatic Vitamin E

546 Concentration of Chickens Fed Wheat Based Diet." Journal of Animal and Feed Sciences

547 24: 80-84. doi.org/10.22358/jafs/65656/2015.

548 PIRGOZLIEV, V., M. W. MIRZA, and S.P. ROSE. 2016. "Does the Effect of Pelleting 549 Depend on the Wheat Sample When Fed to Chickens?. Animal 10: 571-577. 550 doi.org/10.1017/S1751731115002311.

551 PIRGOZLIEV, V., S.C. MANSBRIDGE, S.P. ROSE, A.M. MACKENZIE, A. 552 BECCACCIA, F. KARADAS, S.G. IVANOVA, G.P. STAYKOVA, O.O OLUWATOSIN 553 and D. BRAVO. 2019. "Dietary Essential Oils Improve Feed Efficiency and Hepatic

554 Antioxidant Content of Broiler Chickens." Animal 13: 502-508. 555 doi.org/10.1017/S1751731118001520.

556 PIRGOZLIEV., V. C. WESTBROOK, S. WOODS, S.C. MANSBRIDGE, S.P. ROSE, I.M.

557 WHiting, D. YOVCHEV, A.G. ATANASOV, K. KLJAK, G.P. STAYKOVA, S.

558 IVANOVA, M.R. KARAGECILI, K. KARADAS and J.H. STRINGHINI. 2020. "Feeding

559 Dihydroquercetin and Vitamin E to Broiler Chickens Reared at Standard and High Ambient

560 Temperatures.” BioRxiv: doi.org/10.1101/2020.05.19.104398.

561 POORGHASEMI M., A., SEIDAVI, A.A.A., QOTBI, V., LAUDADIO and V.

562 TUFARELLI. 2013. "Influence of Dietary Fat Source on Growth Performance Responses 563 and Carcass Traits of Broiler Chicks." Asian-Australasian Journal of Animal Sciences 26:

564 705- 710. doi.org/10.5713/ajas.2012.12633.

Accepted for publication 4 August 2020 
565

566

567

568

56900812

570

571

572

573

$574 \quad 2016$

575 "Effects of .

576 and Certain $\mathrm{E}$

577 Animal Science 6: 195-202. http://ijas.iaurasht.ac.ir/article_520975_112215.html.
¿SMAEILIPOUR, O. and KHOSRAVINIA, $\mathrm{H}$.

Performance, Antioxidant Enzyme Activity nian Journal of Applied

579 2017. "Nanoselenium Broilers: Effects on Performance,

580

581

582 doi.org/10.1007/s12011-016-0899-5

583 SALARI, S., H. KERMANSHAHI and H.N. M Effect of Sodium

584 Bentonite and Comparison of Pellet vs. Mash on Performance of Broiler 585 Chickens." International Journal of Poultry Science 5: 31-34. 586 doi.org/10.3923/ijps.2006.31.34.

587 SANTOS, R. R., A. AWATI, P.J. ROUBOS-VAN DEN HIL, M.H.G. TERSTEEG-

588 ZIJDERVELD, P.A. KOOLMEES and J. FINK-GREMMELS. 2015. "Quantitative Histo- 
589 Morphometric Analysis of Heat-Stress-Related Damage in the Small Intestines of Broiler 590 Chickens”. Avian Pathology 44: 19-22. doi.org/10.1080/03079457.2014.988122.

591 SANZ, M. 1999. "Higher Lipid Accumulation in Broilers Fed on Saturated Fats than in 592 Those Fed on Unsaturated Fats." British Poultry Science 40: 95-101. 593 doi.org/10.1080/00071669987908.

594 SANZ, M., C.J. LOPEZ-BOTE, A. FLORES and J.M. CARMONA. 2000. "Effect of the 595 Inclusion Time of Dietary Saturated and Unsaturated Fats before Slaughter on the 596 Accumulation and Composition of Abdominal Fat in Female Broiler Chickens." Poultry 597 Science 79: 1320-1325. doi.org/10.1080/00071660086411.

598 SARICA, S., H. AYDIN and G. CIFTCI. 2017. "Effects of Dietary Supplementation of 599 Some Antioxidants on Liver Antioxidant Status and Plasma Biochemistry Parameters of 600 Heat-Stressed Quail." Turkish Journal of Agriculture-Food Science and Technology 5: 773 $601-779$. doi.org/10.24925/turjaf.v5i7.773-779.1182.

602 ŠEVCIKOVA, S., SKRIVAN, M., G. DLOUHA and M. KOUCKY. 2006. "The Effect of 603 Selenium Source on the Performance and Meat Quality of Broiler Chickens.”

604 Czechoslavakian Journal of Animal Science 51: 449-457.

605 https://www.agriculturejournals.cz/publicFiles/52338.pdf.

606 SLIM R.M., M. TOBOREK, B.A. WATKIN, G.A. BOISSONNEAULT and B. HENNIG. 607 1996. "Susceptibility to Hepatic Oxidative Stress in Rabbits fed Different Animal and Plant 608 Fats." Journal of the American College of Nutrition 15: 289-294. 609 doi.org/10.1080/07315724.1996.10718600.

610 SOHAIL, M.U., M. E. HUME, J. A. BYRD, D. J. NISBET, A. IJAZ, A. SOHAIL, M. Z. 611 SHABBIR and H. REHMAN. 2012. "Effect of Supplementation of Prebiotic Mannan612 oligosaccharides and Probiotic Mixture on Growth Performance of Broilers Subjected to 613 Chronic Heat Stress.” Poultry Science 91: 2235-2240. doi.org/10.3382/ps.2012-02182. 
614 SONAIYA, E. B. 1989. "Effect of Temperature and Dietary Energy on Live Performance 615 Blood Chemistry and Organ Proportions in Broiler Chickens." Journal of the Science of 616 Food and Agriculture 49: 185-192. doi.org/10.1002/jsfa.2740490207.

617 SURAI, P. F. 2002. "Selenium in Poultry Nutrition: Antioxidant Properties, Deficiency and 618 Toxicity." World Poultry Science Journal 58: 333-347. doi.org/10.1079/WPS20020026.

619 SURAI, P.F. 2006. "Selenium in Nutrition and Health." Nottingham University Press, 620 Nottingham, UK.

621 SURAI, P. F., I.I. KOCHISH and V.I. FISININ. 2018a. "Glutathione Peroxidases in Poultry 622 Biology: Part 1. Classification and Mechanisms of Action.” World's Poultry Science 623 Journal, 74: 185-198. doi.org/10.1017/s0043933918000284.

624 SURAI, P. F., I.I. KOCHISH and V.I. FISININ. 2018b. "Glutathione Peroxidases in Poultry 625 Biology: Part 2. Modulation of Enzymatic Activities." World's Poultry Science Journal 74: 239-250. doi.org/10.1017/s0043933918000260.

627 SYAFWAN, S., R.P. KWAKKEL and M.W.A. VERSTEGEN. 2011. "Heat Stress and

630 TANNER, S.D., V.I. BARANOV and D.R. BANDURA. 2002. "Reaction Cells and Collison 631 Cells for ICP-MS: a Tutorial Review.” Spectrochimica Acta, Part B Atomic Spectroscopy 632 57: 1361-1452. doi.org/10.1016/S0584-8547(02)00069-1.

UPTON, J.R., F.W. EDENS and P.R. FERKET 2009. “The Effects of Dietary Oxidized Fat 634 and Selenium Source on Performance, Glutathione Peroxidase, and Glutathione Reductase 635 Activity in Broiler Chickens." Journal of Applied Poultry Research 18: 193-202. doi.org/10.3382/japr.2008-00019.

637 WANG, Y.B. and B.H. XU. 2008. "Effect of Different Selenium Source (Sodium Selenite 638 and Selenium Yeast) on Broiler Chickens." Animal Feed Science and Technology 144: 306-

639 314. doi.org/10.1016/j.anifeedsci.2007.10.012. 
640 WOODS, S.L., S. SOBOLEWSKA, S.P. ROSE, I.M. WHITING, A. BLANCHARD, C. 641 IONESCU, D. BRAVO and V. PIRGOZLIEV. 2020a. "Effect of Feeding Different Sources 642 of Selenium on Growth Performance and Antioxidant Status of Broilers." British Poultry 643 Science. 61: 274-280. doi.org/10.1080/00071668.2020.1716301.

644 WOODS, S.L., S.P. ROSE, I.M. WHITING, C. IONESCU, A. BLANCHARD and V. 645 PIRGOZLIEV. 2020b. “The Effect of Feeding Different Sources and Levels of Selenium on 646 Growth Performance and Antioxidant Status of Broilers Raised at Two Different 647 Temperatures." British Poultry Science, just accepted. 648 doi.org/10.1080/00071668.2020.1782350.

649 YAHAV, S. 1999. "Effect of Early-Age Thermal Conditioning and Food Restriction on 650 Performance and Thermotolerance of Male Broiler Chickens.” British Poultry Science 40: 651 120-126. doi.org/10.1080/00071669987944.

652 YOVCHEV, D., G. PENCHEV, D. DIMITROV and K. STAMATOVA-YOVCHEVA. 653 2019. "Micromorphometric Study of the Small Intestines in Different Post-Hatch Periods in 654 Bronze Turkey (Meleagris meleagris gallopavo).” Bulgarian Journal of Agricultural Science 655 25: 552-557. doi.org/10.15547/tjs.2019.04.002. 656 
657 Table 1. Ingredient composition of the experimental diets (as fed) from 14 to $35 \mathrm{~d}$ of age.

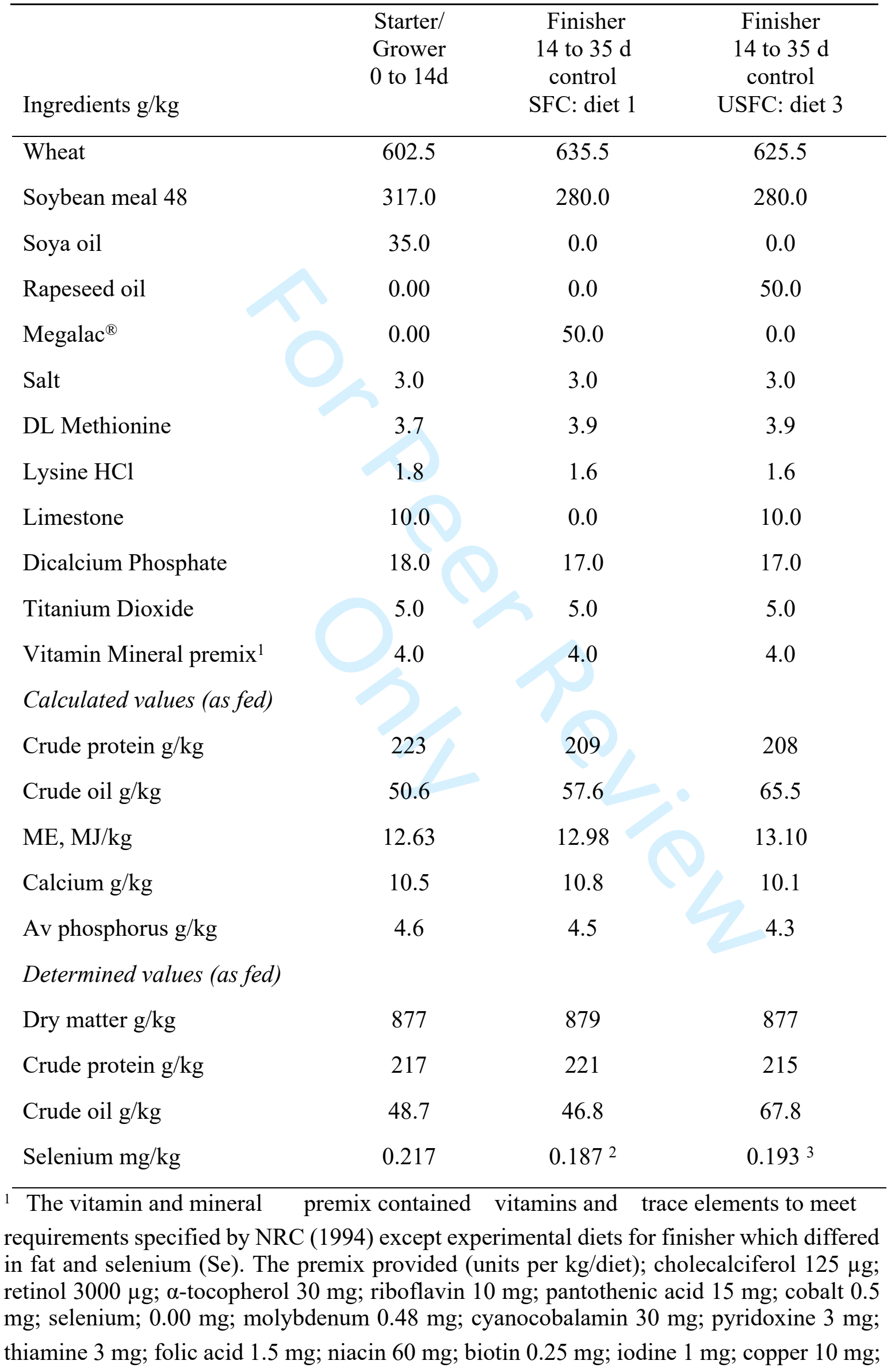


664 iron $20 \mathrm{mg}$; manganese $100 \mathrm{mg}$; zinc $80 \mathrm{mg} .{ }^{2}$ Diet 2 (SFSe) contained $0.247 \mathrm{mg} / \mathrm{kg} \mathrm{Se} .{ }^{3}$

665 Diet 4 (USFSe) contained $0.251 \mathrm{mg} / \mathrm{kg} \mathrm{Se}$

666

667

668 Table 2. The effect of bird rearing temperature $\left(\mathrm{T}^{\circ} \mathrm{C}\right)$, dietary selenium concentration $(\mathrm{Se})$ 669 and fat source (unsaturated (USF) or saturated (SF) fat) on feed intake (FI), weight gain 670 (WG) and feed conversion ratio (FCR) when fed to broilers from 14 to $35 \mathrm{~d}$ of age

\begin{tabular}{|c|c|c|c|}
\hline Treatment factor & $\begin{array}{c}\mathrm{FI} \\
\mathrm{g} / \mathrm{b} / \mathrm{d}\end{array}$ & $\begin{array}{c}\text { WG } \\
\mathrm{g} / \mathrm{b} / \mathrm{d}\end{array}$ & $\begin{array}{c}\text { FCR } \\
\mathrm{g} / \mathrm{g}\end{array}$ \\
\hline \multicolumn{4}{|l|}{$\mathrm{T}^{\circ} \mathrm{C}$} \\
\hline $20^{\circ} \mathrm{C}$ & 109.1 & 67.2 & 1.618 \\
\hline $35^{\circ} \mathrm{C}$ & 59.9 & 28.5 & 2.048 \\
\hline SEM & 1.73 & 1.68 & 0.0467 \\
\hline \multicolumn{4}{|l|}{$\mathrm{Se}$} \\
\hline No & 85.6 & 49.5 & 1.793 \\
\hline Yes & 83.3 & 46.3 & 1.872 \\
\hline SEM & 1.72 & 1.53 & 0.0310 \\
\hline \multicolumn{4}{|l|}{ Fat } \\
\hline USF & 85.8 & 48.8 & 1.819 \\
\hline $\mathrm{SF}$ & 83.1 & 46.9 & 1.846 \\
\hline SEM & 1.72 & 1.53 & 0.0310 \\
\hline \multicolumn{4}{|l|}{$\mathrm{T}^{\circ} \mathrm{C} \times \mathrm{Se}$} \\
\hline $20^{\circ} \mathrm{C} \mathrm{No}$ & 110.0 & 69.5 & 1.586 \\
\hline $20^{\circ} \mathrm{C}$ Yes & 108.1 & 65.0 & 1.649 \\
\hline $35^{\circ} \mathrm{C}$ No & 61.2 & 29.4 & 2.001 \\
\hline $35^{\circ} \mathrm{C} \mathrm{Yes}$ & 58.6 & 27.6 & 2.095 \\
\hline SEM & 2.43 & 2.28 & 0.0560 \\
\hline $\mathrm{T}^{\circ} \mathrm{C} \times$ Fat & & & \\
\hline $20^{\circ} \mathrm{C} \mathrm{USF}$ & 112.5 & 69.9 & 1.588 \\
\hline $20^{\circ} \mathrm{C} \mathrm{SF}$ & 105.7 & 64.6 & 1.647 \\
\hline $35^{\circ} \mathrm{C} \mathrm{USF}$ & 59.2 & 27.7 & 2.050 \\
\hline $35^{\circ} \mathrm{C} \mathrm{SF}$ & 60.5 & 29.3 & 2.046 \\
\hline SEM & 2.43 & 2.28 & 0.0560 \\
\hline \multicolumn{4}{|l|}{ Fat $x \mathrm{Se}$} \\
\hline USF No & 87.7 & 50.5 & 1.764 \\
\hline USF Yes & 84.0 & 47.1 & 1.875 \\
\hline SF No & 83.5 & 48.4 & 1.823 \\
\hline SF Yes & 82.7 & 45.5 & 1.869 \\
\hline SEM & 2.43 & 2.17 & 0.0438 \\
\hline \multicolumn{4}{|l|}{ Probabilities } \\
\hline Temperature & $<0.001$ & $<0.001$ & 0.003 \\
\hline $\mathrm{Se}$ & 0.358 & 0.152 & 0.081 \\
\hline Fat & 0.264 & 0.391 & 0.544 \\
\hline $\mathrm{T}^{\circ} \mathrm{C} \times \mathrm{Se}$ & 0.898 & 0.531 & 0.719 \\
\hline $\mathrm{T}^{\circ} \mathrm{C} \times$ Fat & 0.103 & 0.120 & 0.477 \\
\hline Fat x Se & 0.547 & 0.903 & 0.460 \\
\hline $\mathrm{CV} \%$ & 9.9 & 15.7 & 8.3 \\
\hline
\end{tabular}



$0.193 \mathrm{mg} / \mathrm{kg}$ Se. USFSe: $0.251 \mathrm{mg} / \mathrm{kg} \mathrm{Se}$ 
675 Table 3. The effect of bird rearing temperature $\left(\mathrm{T}^{\circ} \mathrm{C}\right)$, dietary selenium concentration (Se) 676 and fat source (unsaturated (USF) or saturated (SF) fat) on broiler blood glutathione 677 peroxidase (GSH-Px), plasma total antioxidant status (TAS) and Se levels in breast and liver 678 tissue at $35 \mathrm{~d}$ of age

\begin{tabular}{|c|c|c|c|c|}
\hline Treatment factor & $\begin{array}{c}\text { GSH-Px } \\
(\mathrm{u} / \mathrm{ml})\end{array}$ & $\begin{array}{c}\text { TAS } \\
\mathrm{mmol} / \mathrm{l}\end{array}$ & $\begin{array}{c}\text { Se breast } \\
\mathrm{mg} / \mathrm{kg} \mathrm{DM}\end{array}$ & $\begin{array}{c}\text { Se liver } \\
\mathrm{mg} / \mathrm{kg} \text { DM }\end{array}$ \\
\hline \multicolumn{5}{|l|}{$\mathrm{T}^{\circ} \mathrm{C}$} \\
\hline $20^{\circ} \mathrm{C}$ & 155.7 & 0.809 & 0.764 & 2.461 \\
\hline $35^{\circ} \mathrm{C}$ & 130.1 & 1.005 & 0.854 & 2.430 \\
\hline SEM & 21.23 & 0.0806 & 0.0305 & 0.1006 \\
\hline \multicolumn{5}{|l|}{$\mathrm{Se}$} \\
\hline No & 124.4 & 0.865 & 0.792 & 2.325 \\
\hline Yes & 161.4 & 0.948 & 0.826 & 2.565 \\
\hline SEM & 7.16 & 0.0617 & 0.0145 & 0.0314 \\
\hline \multicolumn{5}{|l|}{ Fat } \\
\hline USF & 139.2 & 0.870 & 0.802 & 2.428 \\
\hline SF & 146.6 & 0.943 & 0.816 & 2.463 \\
\hline SEM & 7.16 & 0.0617 & 0.0145 & 0.0314 \\
\hline \multicolumn{5}{|l|}{$\mathrm{T}^{\circ} \mathrm{C} \times \mathrm{Se}$} \\
\hline $20^{\circ} \mathrm{C} \mathrm{No}$ & $126.6^{\mathrm{a}}$ & 0.761 & 0.746 & $2.286^{\mathrm{a}}$ \\
\hline $20^{\circ} \mathrm{C}$ Yes & $184.8^{\mathrm{b}}$ & 0.857 & 0.783 & $2.637^{\mathrm{b}}$ \\
\hline $35^{\circ} \mathrm{C} \mathrm{No}$ & $122.2^{\mathrm{a}}$ & 0.970 & 0.839 & $2.365^{\mathrm{ab}}$ \\
\hline $35^{\circ} \mathrm{C}$ Yes & $137.9^{\mathrm{a}}$ & 1.040 & 0.869 & $2.494^{\mathrm{ab}}$ \\
\hline SEM & 22.40 & 0.1016 & 0.0337 & 0.1054 \\
\hline \multicolumn{5}{|l|}{$\mathrm{T}^{\circ} \mathrm{C} \times$ Fat } \\
\hline $20^{\circ} \mathrm{C} \mathrm{USF}$ & 143.9 & 0.787 & 0.753 & 2.451 \\
\hline $20^{\circ} \mathrm{C} \mathrm{SF}$ & 167.5 & 0.830 & 0.776 & 2.472 \\
\hline $35^{\circ} \mathrm{C} \mathrm{USF}$ & 134.5 & 0.953 & 0.851 & 2.406 \\
\hline $35^{\circ} \mathrm{C} \mathrm{SF}$ & 125.6 & 1.057 & 0.857 & 2.453 \\
\hline SEM & 22.40 & 0.1016 & 0.0337 & 0.1054 \\
\hline \multicolumn{5}{|l|}{ Fat $\times \mathrm{Se}$} \\
\hline USF No & 114.2 & 0.870 & $0.763^{a}$ & 2.284 \\
\hline USF Yes & 164.2 & 0.871 & $0.842^{b}$ & 2.573 \\
\hline SF No & 134.6 & 0.861 & $0.822^{\mathrm{ab}}$ & 2.367 \\
\hline SF Yes & 158.6 & 1.026 & $0.810^{\mathrm{ab}}$ & 2.558 \\
\hline SEM & 10.12 & 0.0873 & 0.0205 & 0.0444 \\
\hline \multicolumn{5}{|l|}{ Probabilities } \\
\hline Temperature & 0.441 & 0.160 & 0.106 & 0.835 \\
\hline $\mathrm{Se}$ & 0.001 & 0.349 & 0.110 & $<0.001$ \\
\hline Fat & 0.473 & 0.409 & 0.495 & 0.447 \\
\hline $\mathrm{T}^{\circ} \mathrm{C} \times \mathrm{Se}$ & 0.046 & 0.883 & 0.842 & 0.017 \\
\hline $\mathrm{T}^{\circ} \mathrm{C} \times \mathrm{Fat}$ & 0.120 & 0.730 & 0.694 & 0.766 \\
\hline Fat $x$ Se & 0.213 & 0.353 & 0.033 & 0.284 \\
\hline CV \% & 24.5 & 33.4 & 8.8 & 6.3 \\
\hline
\end{tabular}

$679 \mathrm{SEM}=$ pooled standard errors of mean; $\mathrm{CV} \%=$ coefficient of variation. Each diet was fed 680 to birds in 12 pens. Means within a column with no common superscript differ significantly 58 681 (P<0.05). SFC: $0.187 \mathrm{mg} / \mathrm{kg} \mathrm{Se} ;$ SFSe: $0.247 \mathrm{mg} / \mathrm{kg} \mathrm{Se}$. USFC: $0.193 \mathrm{mg} / \mathrm{kg}$ Se. USFSe: ${ }^{59}$ $6820.251 \mathrm{mg} / \mathrm{kg} \mathrm{Se}$ 
685 Table 4. The effect of bird rearing temperature $\left(\mathrm{T}^{\circ} \mathrm{C}\right)$, dietary selenium concentration (Se) 686 and fat source (unsaturated (USF) or saturated (SF) fat) on broiler organ percentage (\%) 687 weight to body weight including the proventriculus and gizzard (PG); small intestine (SI); 688 pancreas; spleen; liver, heart and caeca at $35 \mathrm{~d}$ of age

\begin{tabular}{|c|c|c|c|c|c|c|c|c|}
\hline $\begin{array}{l}\text { Treatment } \\
\text { factor }\end{array}$ & $\begin{array}{l}\text { BW } \\
35 d\end{array}$ & PG & SI & Pancreas & Caeca & Spleen & Liver & Heart \\
\hline \multicolumn{9}{|l|}{$\mathrm{T}^{\circ} \mathrm{C}$} \\
\hline $20^{\circ} \mathrm{C}$ & 1.893 & 1.912 & 2.974 & 0.2552 & 0.511 & 0.0841 & 2.112 & 0.619 \\
\hline $35^{\circ} \mathrm{C}$ & 1.028 & 1.905 & 2.459 & 0.2462 & 0.523 & 0.0489 & 1.625 & 0.389 \\
\hline SEM & - & 0.0545 & 0.1180 & 0.01188 & 0.0285 & 0.00446 & 0.0636 & 0.0143 \\
\hline \multicolumn{9}{|c|}{ 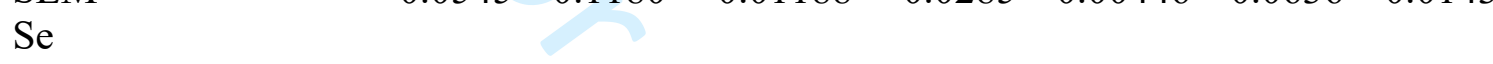 } \\
\hline No & 1.491 & 1.910 & 2.737 & 0.2449 & 0.528 & 0.0655 & 1.859 & 0.498 \\
\hline Yes & 1.430 & 1.907 & 2.697 & 0.2564 & 0.506 & 0.0676 & 1.877 & 0.509 \\
\hline SEM & - & 0.0430 & 0.0663 & 0.00979 & 0.0248 & 0.00393 & 0.0391 & 0.0151 \\
\hline \multicolumn{9}{|l|}{ Fat } \\
\hline USF & $1.50 Y$ & 1.894 & 2.133 & $0.23 / 6$ & 0.541 & 0.0649 & 1.866 & 0.495 \\
\hline $\mathrm{SF}$ & 1.412 & 1.923 & 2.700 & 0.2638 & 0.492 & 0.0681 & 1.871 & 0.512 \\
\hline SEM & - & 0.0430 & 0.0663 & 0.00979 & 0.0248 & 0.00393 & 0.0391 & 0.0151 \\
\hline \multicolumn{9}{|l|}{$\mathrm{T}^{\circ} \mathrm{C} \times \mathrm{Se}$} \\
\hline $20^{\circ} \mathrm{C} \mathrm{No}$ & 1.930 & 1.928 & 2.981 & 0.2551 & 0.515 & 0.0819 & 2.091 & 0.617 \\
\hline $20^{\circ} \mathrm{C}$ Yes & 1.856 & 1.896 & 2.968 & 0.2553 & 0.507 & 0.0862 & 2.132 & 0.620 \\
\hline $35^{\circ} \mathrm{C} \mathrm{No}$ & 1.052 & 1.892 & 2.493 & 0.2348 & 0.541 & 0.0490 & 1.628 & 0.380 \\
\hline $35^{\circ} \mathrm{C}$ Yes & 1.003 & 1.918 & 2.426 & 0.2576 & 0.506 & 0.0489 & 1.623 & 0.398 \\
\hline SEM & - & 0.0694 & 0.1354 & 0.01540 & 0.0378 & 0.00595 & 0.0747 & 0.0207 \\
\hline \multicolumn{9}{|l|}{$\mathrm{T}^{\circ} \mathrm{C} \times$ Fat } \\
\hline $20^{\circ} \mathrm{C}$ USF & 1.997 & 1.891 & 2.939 & 0.2301 & 0.506 & 0.0778 & 2.101 & 0.616 \\
\hline $20^{\circ} \mathrm{C} \mathrm{SF}$ & 1.789 & 1.934 & 3.009 & 0.2802 & 0.515 & 0.0904 & 2.122 & 0.621 \\
\hline $35^{\circ} \mathrm{C} \mathrm{USF}$ & 1.020 & 1.897 & 2.527 & 0.2451 & 0.577 & 0.0521 & 1.631 & 0.375 \\
\hline $35^{\circ} \mathrm{C} \mathrm{SF}$ & 1.035 & 1.913 & 2.392 & 0.2474 & 0.469 & 0.0458 & 1.619 & 0.403 \\
\hline SEM & - & 0.0694 & 0.1354 & 0.01540 & 0.0378 & 0.00595 & 0.0747 & 0.0207 \\
\hline \multicolumn{9}{|l|}{ Fat $x$ Se } \\
\hline USF No & 1.569 & 1.885 & 2.784 & 0.2277 & 0.556 & 0.0601 & 1.835 & 0.501 \\
\hline USF Yes & 1.448 & 1.903 & 2.683 & 0.2475 & 0.527 & 0.0697 & 1.897 & 0.490 \\
\hline SF No & 1.414 & 1.935 & 2.691 & 0.2622 & 0.500 & 0.0708 & 1.883 & 0.496 \\
\hline SF Yes & 1.411 & 1.912 & 2.710 & 0.2654 & 0.485 & 0.0654 & 1.858 & 0.528 \\
\hline SEM & - & 0.0608 & 0.0938 & 0.01384 & 0.0351 & 0.00556 & 0.0554 & 0.0213 \\
\hline \multicolumn{9}{|l|}{ Probabilities } \\
\hline Temperature & - & 0.930 & 0.037 & 0.622 & 0.768 & 0.005 & 0.006 & $<0.001$ \\
\hline $\mathrm{Se}$ & - & 0.964 & 0.669 & 0.412 & 0.543 & 0.706 & 0.746 & 0.626 \\
\hline Fat & - & 0.633 & 0.727 & 0.066 & 0.170 & 0.571 & 0.930 & 0.438 \\
\hline $\mathrm{T}^{\circ} \mathrm{C} \times \mathrm{Se}$ & - & 0.630 & 0.777 & 0.420 & 0.702 & 0.697 & 0.674 & 0.730 \\
\hline $\mathrm{T}^{\circ} \mathrm{C} \times$ Fat & - & 0.824 & 0.281 & 0.092 & 0.104 & 0.099 & 0.763 & 0.610 \\
\hline Fat $x$ Se & - & 0.741 & 0.527 & 0.552 & 0.839 & 0.185 & 0.442 & 0.334 \\
\hline $\mathrm{CV} \%$ & - & 11.0 & 12.0 & 19.1 & 0.596 & 29.0 & 10.3 & 14.6 \\
\hline
\end{tabular}

$689 \mathrm{BW}=$ body weight of dissected bird; SEM = pooled standard errors of mean; $\mathrm{CV} \%=$ 690 coefficient of variation. Each diet was fed to birds in 12 pens. SFC: $0.187 \mathrm{mg} / \mathrm{kg} \mathrm{Se}$ 
691 SFSe: $0.247 \mathrm{mg} / \mathrm{kg}$ Se. USFC: $0.193 \mathrm{mg} / \mathrm{kg} \mathrm{Se}$. USFSe: $0.251 \mathrm{mg} / \mathrm{kg} \mathrm{Se}$ 
693 Table 5. The effect of bird rearing temperature $\left(\mathrm{T}^{\circ} \mathrm{C}\right)$, dietary selenium concentration (Se) 694 and fat source (unsaturated (USF) or saturated (SF) fat) on N-corrected apparent 695 metabolisable energy (AMEn MJ/kg DM), dry matter retention (DMR), fat retention (FR) 696 and nitrogen retention (NR) coefficients (determined between 32 and $35 \mathrm{~d}$ of age).

\begin{tabular}{|c|c|c|c|c|}
\hline Treatment factor & AMEn & DMR & FR & NR \\
\hline \multicolumn{5}{|l|}{$\mathrm{T}^{\circ} \mathrm{C}$} \\
\hline $20^{\circ} \mathrm{C}$ & 13.64 & 0.728 & 0.757 & 0.673 \\
\hline $35^{\circ} \mathrm{C}$ & 13.55 & 0.703 & 0.769 & 0.514 \\
\hline SEM & 0.170 & 0.0145 & 0.0042 & 0.0215 \\
\hline \multicolumn{5}{|l|}{$\mathrm{Se}$} \\
\hline No & 13.74 & 0.7253 & 0.776 & 0.602 \\
\hline Yes & 13.45 & 0.7053 & 0.750 & 0.584 \\
\hline SEM & 0.123 & 0.0079 & 0.0112 & 0.0109 \\
\hline \multicolumn{5}{|l|}{ Fat } \\
\hline USF & 13.80 & 0.724 & 0.825 & 0.604 \\
\hline $\mathrm{SF}$ & 13.40 & 0.706 & 0.704 & 0.582 \\
\hline SEM & 0.123 & 0.0079 & 0.0112 & 0.0109 \\
\hline \multicolumn{5}{|l|}{$\mathrm{T}^{\circ} \mathrm{C} \times \mathrm{Se}$} \\
\hline $20^{\circ} \mathrm{C} \mathrm{No}$ & 13.73 & 0.733 & 0.774 & 0.677 \\
\hline $20^{\circ} \mathrm{C}$ Yes & 13.55 & 0.722 & 0.741 & 0.669 \\
\hline $35^{\circ} \mathrm{C} \mathrm{No}$ & 13.75 & 0.717 & 0.778 & 0.528 \\
\hline $35^{\circ} \mathrm{C}$ Yes & 13.36 & 0.688 & 0.759 & 0.499 \\
\hline SEM & 0.209 & 0.0165 & 0.0119 & 0.0241 \\
\hline \multicolumn{5}{|l|}{$\mathrm{T}^{\circ} \mathrm{C} \times$ Fat } \\
\hline $20^{\circ} \mathrm{C} \mathrm{USF}$ & 13.97 & 0.745 & 0.830 & 0.698 \\
\hline $20^{\circ} \mathrm{C} \mathrm{SF}$ & 13.31 & 0.712 & 0.685 & 0.648 \\
\hline $35^{\circ} \mathrm{C} \mathrm{USF}$ & 13.62 & 0.704 & 0.819 & 0.511 \\
\hline $35^{\circ} \mathrm{C} \mathrm{SF}$ & 13.49 & 0.702 & 0.718 & 0.516 \\
\hline SEM & 0.209 & 0.0165 & 0.0119 & 0.0241 \\
\hline \multicolumn{5}{|l|}{ Fat $x$ Se } \\
\hline USF No & 13.80 & 0.725 & 0.834 & 0.601 \\
\hline USF Yes & 13.80 & 0.724 & 0.815 & 0.608 \\
\hline SF No & 13.68 & 0.726 & 0.717 & 0.604 \\
\hline SF Yes & 13.11 & 0.686 & 0.685 & 0.560 \\
\hline SEM & 0.174 & 0.0111 & 0.0159 & 0.0154 \\
\hline \multicolumn{5}{|l|}{ Probabilities } \\
\hline Temperature & 0.734 & 0.292 & 0.136 & 0.006 \\
\hline $\mathrm{Se}$ & 0.111 & 0.082 & 0.119 & 0.244 \\
\hline Fat & 0.028 & 0.111 & $<0.001$ & 0.158 \\
\hline $\mathrm{T}^{\circ} \mathrm{C} \times \mathrm{Se}$ & 0.541 & 0.419 & 0.673 & 0.526 \\
\hline $\mathrm{T}^{\circ} \mathrm{C} \times$ Fat & 0.132 & 0.170 & 0.170 & 0.082 \\
\hline Fat $x$ Se & 0.113 & 0.085 & 0.689 & 0.100 \\
\hline $\mathrm{CV} \%$ & 4.4 & 5.4 & 7.2 & 9.0 \\
\hline
\end{tabular}

$697 \mathrm{SEM}=$ pooled standard errors of mean; $\mathrm{CV} \%=$ coefficient of variation; Each diet was fed 698 to birds in 12 pens. SFC: $0.187 \mathrm{mg} / \mathrm{kg}$ Se. SFSe: $0.247 \mathrm{mg} / \mathrm{kg}$ Se. USFC: $0.193 \mathrm{mg} / \mathrm{kg} \mathrm{Se}$. 699 USFSe: $0.251 \mathrm{mg} / \mathrm{kg} \mathrm{Se}$ 
702 Table 6. The effect of bird rearing temperature $\left(\mathrm{T}^{\circ} \mathrm{C}\right)$, dietary selenium concentration $(\mathrm{Se})$ 703 and fat source (unsaturated (USF) or saturated (SF) fat) on jejunal villus height (VH), villus 704 width (VW), crypt depth (CD) and VH:CD ratio. All measurements in micrometre $(\mu \mathrm{m})$ at $70535 \mathrm{~d}$ of age.

\begin{tabular}{|c|c|c|c|c|}
\hline Treatment factor & $\mathrm{VH}$ & $\mathrm{VW}$ & $\mathrm{CD}$ & $\mathrm{VH}: \mathrm{CD}$ \\
\hline \multicolumn{5}{|l|}{$\mathrm{T}^{\circ} \mathrm{C}$} \\
\hline $20^{\circ} \mathrm{C}$ & 872.2 & 131.4 & 138.9 & 6.27 \\
\hline $35^{\circ} \mathrm{C}$ & 872.5 & 130.6 & 139.1 & 6.25 \\
\hline SEM & 7.35 & 0.42 & 0.32 & 0.048 \\
\hline \multicolumn{5}{|l|}{$\mathrm{Se}$} \\
\hline No & 823.9 & 116.7 & 132.9 & 6.20 \\
\hline Yes & 920.8 & 145.4 & 145.1 & 6.32 \\
\hline SEM & 5.09 & 0.54 & 0.32 & 0.041 \\
\hline \multicolumn{5}{|l|}{ Fat } \\
\hline USF & 989.2 & 141.3 & 154.9 & 6.38 \\
\hline SF & 755.6 & 120.8 & 123.1 & 6.14 \\
\hline SEM & 5.09 & 0.54 & 0.32 & 0.041 \\
\hline \multicolumn{5}{|l|}{$\mathrm{T}^{\circ} \mathrm{C} \times \mathrm{Se}$} \\
\hline $20^{\circ} \mathrm{C} \mathrm{No}$ & 820.3 & 117.6 & 132.7 & 6.18 \\
\hline $20^{\circ} \mathrm{C}$ Yes & 924.1 & 145.3 & 145.2 & 6.35 \\
\hline $35^{\circ} \mathrm{C} \mathrm{No}$ & 827.5 & 115.7 & 133.2 & 6.22 \\
\hline $35^{\circ} \mathrm{C}$ Yes & 917.6 & 145.6 & 145.0 & 6.29 \\
\hline SEM & 8.94 & 0.69 & 0.46 & 0.063 \\
\hline \multicolumn{5}{|l|}{$\mathrm{T}^{\circ} \mathrm{C} \times$ Fat } \\
\hline $20^{\circ} \mathrm{C} \mathrm{USF}$ & 982.6 & 141.3 & 154.8 & 6.34 \\
\hline $20^{\circ} \mathrm{C} \mathrm{SF}$ & 761.8 & 121.6 & 123.1 & 6.19 \\
\hline $35^{\circ} \mathrm{C} \mathrm{USF}$ & 995.7 & 141.3 & 155.0 & 6.42 \\
\hline $35^{\circ} \mathrm{C} \mathrm{SF}$ & 749.3 & 120.0 & 123.2 & 6.09 \\
\hline SEM & 8.94 & 0.69 & 0.46 & 0.063 \\
\hline \multicolumn{5}{|l|}{ Fat x Se } \\
\hline USF No & $929.4^{\mathrm{a}}$ & $122.8^{\mathrm{a}}$ & $150.1^{\mathrm{a}}$ & $6.19^{a}$ \\
\hline USF Yes & $1049.0^{b}$ & $159.7^{b}$ & $159.7^{b}$ & $6.57^{b}$ \\
\hline SF No & $718.4^{\mathrm{c}}$ & $110.5^{\mathrm{c}}$ & $115.8^{\mathrm{c}}$ & $6.21^{\mathrm{a}}$ \\
\hline SF Yes & $792.7^{d}$ & $131.1^{\mathrm{d}}$ & $130.5^{\mathrm{d}}$ & $6.07^{\mathrm{a}}$ \\
\hline SEM & 7.20 & 0.76 & 0.45 & 0.058 \\
\hline \multicolumn{5}{|l|}{ Probabilities } \\
\hline Temperature & 0.976 & 0.245 & 0.726 & 0.863 \\
\hline $\mathrm{Se}$ & $<0.001$ & $<0.001$ & $<0.001$ & 0.039 \\
\hline Fat & $<0.001$ & $<0.001$ & $<0.001$ & $<0.001$ \\
\hline $\mathrm{T}^{\circ} \mathrm{C} \times \mathrm{Se}$ & 0.346 & 0.153 & 0.458 & 0.422 \\
\hline $\mathrm{T}^{\circ} \mathrm{C} \times$ Fat & 0.085 & 0.300 & 0.964 & 0.138 \\
\hline Fat $x$ Se & 0.003 & $<0.001$ & $<0.001$ & $<0.001$ \\
\hline CV \% & 2.9 & 2.0 & 1.1 & 3.2 \\
\hline
\end{tabular}

$706 \mathrm{SEM}=$ pooled standard errors of mean; $\mathrm{CV} \%=$ coefficient of variation. Each diet was fed 707 to birds in 12 pens. Means within a column with no common superscript differ significantly 55 708 (P<0.05). SFC: $0.187 \mathrm{mg} / \mathrm{kg}$ Se. SFSe: $0.247 \mathrm{mg} / \mathrm{kg}$ Se. USFC: $0.193 \mathrm{mg} / \mathrm{kg} \mathrm{Se}$. USFSe: $7090.251 \mathrm{mg} / \mathrm{kg} \mathrm{Se}$

710

711 